\title{
PENGEMBANGAN SOAL TES UNTUK MENGUKUR KEMAMPUAN PEMECAHAN MASALAH SISWA PADA MATERI BENTUK ALJABAR
}

\author{
Tita Elisya Wibowo ${ }^{*}$ (iD), Siti Faizah² \\ Universitas Hasyim Asy'ari Tebuireng, Jombang, Indonesia \\ ${ }^{1 *}$ titaelisya07@gmail.com, ${ }^{2}$ faizah.siti91@gmail.com
}

Received: September 30,2021 Revised: October 30, 2021 $\quad$ Accepted: November 24, 2021

\begin{abstract}
:
Problem-solving ability became a learned process as well as a goal that must be achieved in learned mathematics so it is important for students to have these abilities, especially in algebraic form material. But in fact, in the material of algebraic forms, the ability was still minimally mastered by students. Based on the results of the interview, it shows that the lack of ability was due to the questions given by the teacher only in the form of routine questions taken from LKS or textbooks that did not require the use of problem-solving skills but only require the used of procedural formulas. Therefore, it was necessary to develop test questions that contain question items that could measure students' problem-solving abilities in the algebraic form of material. This type of research was developed researched using the ADDIE model which stands for analysis, design, development, implementation, and evaluation. Data collection techniques used in this study were validation questionnaires and tests. Meanwhile, the data collection instruments were validation questionnaire sheets and test sheets. The test subjects in this study were class VII C students of MTs Salafiyah Syafi'iyah Seblak Jombang. The results showed that the product developed in the form of a test was declared valid by the expert with an average validity of 3.75 and was in very valid criteria. Meanwhile, the results of the empirical validity test showed that only four of the five items on the test developed were declared valid and of the four items that were valid, the reliability value of 0.786 with high criteria was obtained. The research findings prove that the developed test contains only four items that were valid both theoretically and empirically and reliably so that they could be used to measure students' problem-solving abilities on the algebraic form of material.
\end{abstract}

Keywords: Development, test, ability, problem-solving, algebraic form.

How to Cite: Wibowo, T. E., \& Faizah, S. (2021). Pengembangan Soal Tes untuk Mengukur Kemampuan Pemecahan Masalah Siswa pada Materi Bentuk Aljabar. Alifmatika: Jurnal Pendidikan dan Pembelajaran Matematika, 3(2), 145-158. https://doi.org/10.35316/alifmatika.2021.v3i2.145158

\section{PENDAHULUAN}

Matematika merupakan satu dari beberapa disiplin ilmu yang wajib diajarkan kepada siswa di semua jenjang pendidikan mulai dari pendidikan dasar hingga ke pendidikan menengah. Sumartini (2016) menjelaskan bahwa mata pelajaran matematika wajib diberikan kepada siswa mulai dari sekolah dasar sampai sekolah menengah untuk mewujudkan harapan agar siswa memiliki kemampuan matematika, salah satunya yaitu kemampuan pemecahan masalah. Kemampuan pemecahan masalah menurut Tarigan (2012) merupakan kemampuan yang diajarkan sebagai bagian dari kurikulum inti matematika yang sangat penting karena siswa dituntut untuk terlihat aktif dalam proses pembelajaran dan

Content from this work may be used under the terms of the Creative Commons AttributionShareAlike 4.0 International License that allows others to share the work with an acknowledgment of the work's authorship and initial publication in this journal. 
pemecahan masalah, siswa dimungkinkan memeroleh pengalaman baru menggunakan pengetahuan dan keterampilan yang telah dimilikinya untuk digunakan dalam memecahkan permasalahan yang bersifat tidak rutin. Pada pembelajaran matematika permasalahan yang sering ditemui oleh siswa biasanya berupa soal yang tidak dapat diselesaikan dengan menggunakan strategi yang biasa digunakan oleh siswa, melainkan harus melalui beberapa strategi yang tepat (Hendriana \& Sumarmo, 2014). Pada pembelajaran matematika menurut Amam (2017) kemampuan siswa dalam mengatasi masalah yang bersifat tidak rutin yang disajikan dalam bentuk soal matematika tekstual maupun kontekstual disebut sebagai kemampuan pemecahan masalah. Berdasarkan ulasan yang telah dipaparkan, dapat diartikan bahwa kemampuan pemecahan masalah dalam pembelajaran matematika merupakan kemampuan siswa dalam menyelesaikan soal matematika yang bersifat tidak rutin serta proses penyelesaiannya tidak dapat menggunakan prosedur rutin yang diketahui oleh siswa, namun harus menggunakan prosedur-prosedur yang tepat.

Rambe \& Afri (2020) menjelaskan bahwa dalam pembelajaran matematika kemampuan pemecahan masalah sangat penting dimiliki oleh siswa. Memiliki kemampuan pemecahan masalah menurut Medyasari, Zaenuri, \& Dewi (2020) dapat membantu siswa berpikir analitis saat membuat keputusan dan meningkatkan kemampuan berpikir kritis ketika dihadapkan pada keadaan yang tidak terduga dalam kehidupan sehari-hari. Namun, fakta di lapangan kemampuan pemecahan masalah secara optimal belum dimiliki oleh siswa. Hasil tes PISA pada tahun 2018 yang diadakan untuk mengukur tingkat kemampuan siswa dalam menggunakan pengetahuan dan keterampilan matematika yang dimiliki dalam mengatasi masalah sehari-hari menunjukkan bahwa Indonesia berada pada peringkat ke 72 dari 78 negara yang mengikuti tes dengan skor rata-rata 379 , sehingga diketahui bahwa kemampuan matematika siswa Indonesia masih berada dalam kategori sangat rendah (Schleicher, 2019; Tohir, 2019). Selain itu, hasil tes TIMSS pada tahun 2015 yang diadakan untuk mengukur kemampuan matematika siswa menunjukkan bahwa Indonesia masih berada pada peringkat bawah yaitu peringkat ke 44 dari 49 negara yang mengikuti tes dengan skor rata-rata 397 (Hadi \& Novaliyosi, 2019; Tohir, 2016).

Sejalan dengan hasil tes PISA dan TIMSS yang telah dipaparkan, hasil survei juga membuktikan bahwa di salah satu sekolah pada jenjang menengah pertama di Jombang menunjukkan bahwa kemampuan pemecahan masalah siswa dalam pembelajaran matematika masih belum maksimal sehingga harus lebih diperhatikan terutama pada materi bentuk aljabar. 65\% siswa mengalami kesulitan dalam menyelesaikan soal-soal bentuk aljabar yang tidak sesuai dengan contoh yang diberikan oleh guru. Namun, ketika guru mengajukan pertanyaan yang sama dengan contoh, siswa dapat menjawab pertanyaan dengan cepat. Sementara itu, materi bentuk aljabar merupakan salah satu kompetensi dalam Kurikulum 2013 yang harus dicapai siswa pada jenjang sekolah menengah pertama pada mata pelajaran matematika adalah memiliki kemampuan dalam memecahkan permasalahan dalam kehidupan sehari-hari yang berkaitan dengan bentuk dan operasi aljabar (Permendikbud, 2016). Pada materi bentuk aljabar diajarkan cara menyederhanakan kalimat menjadi sebuah model matematika untuk mempermudah siswa dalam memecahkan permasalahan pada kehidupan

Alifmatika: Jurnal Pendidikan dan Pembelajaran Matematika, Desember 2021, Vol. 3, No. 2 


\section{Tita Elisya Wibowo \& Siti Faizah}

sehari-hari. Penyederhanaan kalimat menjadi sebuah model matematika dimulai dengan memperkenalkan variabel dan beberapa simbol matematika kepada siswa. sejalan dengan Hidayani (2012) yang menjelaskan bahwa dalam aljabar siswa diperkenalkan mengenai variabel dan berbagai simbol matematika yang biasanya berupa huruf untuk merepresentasikan bilangan secara umum sebagai sarana penyederhanaan dan alat bantu dalam memecahkan permasalahan. Berdasarkan hasil wawancara dengan guru di salah satu sekolah menengah pertama di Jombang menunjukkan bahwa minimnya kemampuan pemecahan masalah disebabkan oleh soal-soal yang diberikan guru kepada siswa hanya berupa soal rutin yang diambil dari LKS atau buku paket yang bukan menuntut penggunaan kemampuan pemecahan masalah melainkan hanya menuntut penggunaan rumus-rumus prosedural. Sejalan dengan Murni (2014) menjelaskan bahwa kurangnya kemampuan pemecahan masalah siswa dalam pembelajaran matematika dikarenakan siswa lebih sering diberikan soal-soal rutin daripada soal tidak rutin sehingga siswa akan mengalami kesulitan dalam menyelesaikan soal yang bersifat tidak rutin.

Berdasarkan ulasan yang telah dipaparkan, maka perlu dilakukan perbaikan pada kualitas pendidikan khususnya pada kegiatan pengukuran kemampuan pemecahan masalah siswa terutama pada materi bentuk aljabar. Sinaga (2016) menjelaskan bahwa penting bagi guru melakukan pengukuran kemampuan siswa dengan baik karena dapat membantu guru dalam mengetahui pengetahuan dan keterampilan yang dikuasai oleh siswa serta dapat mengetahui penyebab ketidakberhasilan siswa dalam pembelajaran secara efektif sehingga mutu kegiatan belajar dan hasil belajar siswa dapat meningkat. Pengukuran kemampuan pemecahan masalah dapat dilakukan dengan memberikan soal-soal yang tidak secara langsung dapat diselesaikan oleh siswa. Sejalan dengan Suyadi menjelaskan bahwa item soal dapat dikatakan masalah paling tidak memuat dua hal yaitu item soal yang menantang pikiran siswa dan item soal yang tidak otomatis dapat diketahui penyelesaiannya (Wijayanti, 2021). Item-item soal tersebut dirakit menjadi sebuah alat ukur yaitu tes. Setiyawan \& Wijayanti (2020) menjelaskan bahwa tes merupakan alat yang digunakan untuk mengukur pengetahuan dan keterampilan siswa dalam menyelesaikan sebuah permasalahan. Sanjaya (2017) menjelaskan bahwa tes merupakan alat yang digunakan untuk mengukur keberhasilan siswa dalam mencapai suatu kompetensi tertentu. Bentuk tes yang tepat untuk mengukur kemampuan pemecahan masalah adalah bentuk tes uraian. Sejalan dengan Arikunto (2021) menjelaskan bahwa tes uraian memiliki kelebihan yaitu dapat mendukung sudut pandang siswa dalam memecahkan soal dan memberi kesempatan siswa dalam mengemukakan ide sehingga tepat jika digunakan untuk mengukur kemampuan pemecahan masalah siswa.

Tes dibuat dengan memerhatikan kelayakan dan kualitasnya. Kelayakan dan kualitas tes dapat dilihat dari dua kriteria yaitu validitas dan reliabilitas. Tes dikatakan valid jika dapat mengukur apa yang akan diukur. Sedangkan tes dikatakan reliabel jika dilakukan secara berulang terhadap subjek yang sama maka hasil tes konsisten (Arifin, 2009). Terdapat empat macam validitas yaitu validitas isi, validitas konstruk, validitas konkuren, dan validitas prediksi. Validitas isi berkaitan dengan kesesuaian antara tujuan tes dengan materi yang diberikan oleh guru. Validitas konstruk berkaitan dengan kesesuaian antara bentuk tes yang

Alifmatika: Jurnal Pendidikan dan Pembelajaran Matematika, Desember 2021, Vol. 3, No. 2 
dibuat dengan tujuan dari tes. Validitas konkuren berkaitan dengan apakah hasil uji validitas yang dilakukan memiliki korelasi dengan tes lain dengan tujuan yang sama. Sedangkan validitas prediksi berkaitan dengan apakah tes yang dibuat secara akurat dapat meramalkan apa yang akan terjadi di masa datang. Validitas isi dan konstruk biasa dikenal dengan validitas teoritis yang didasarkan pada ketentuan atau teori. Artinya ketercapaian kedua validitas tersebut dapat diketahui melalui pemikiran dan/atau penilaian dari ahli terhadap aspek yang akan dinilai. Sedangkan validitas konkuren dan prediksi biasa dikenal dengan validitas empiris yang didasarkan pada bukti melalui pengalaman. Artinya ketercapaian kedua validitas tersebut dapat diketahui melalui uji coba (Arikunto, 2021).

Beberapa penelitian terkait pengembangan soal tes untuk mengukur kemampuan pemecahan masalah telah dilakukan peneliti sebelumnya pada berbagai materi, antara lain: Angriani, Nursalam, Fuadah, \& Baharuddin (2018) mengembangkan tes pada materi perbandingkan, aritmatika sosial, garis dan sudut, segitiga dan segiempat, dan penyajian data dan tes yang dikembangkan layak dan memiliki kualitas tes yang baik sehingga dapat digunakan untuk mengukur kemampuan pemecahan masalah siswa SMP/MTs. Selain itu Sinaga (2016) mengembangkan tes pada materi relasi dan fungsi, persamaan garis lurus, SPLDV, lingkaran, pythagoras, dan bangun ruang sisi datar dan hasil penelitiannya menunjukkan bahwa tes yang dikembangkan memenuhi karakteristik tes yang baik sehingga dapat digunakan untuk mengukur kemampuan siswa SMP/MTs. Pada penelitian ini peneliti mengembangkan tes dalam bentuk uraian pada materi bentuk aljabar. Materi bentuk aljabar dipilih karena dalam materi ini diajarkan cara menyederhanakan kalimat menjadi sebuah model matematika untuk mempermudah siswa dalam memecahkan masalah sehingga jika siswa menemukan permasalahan dalam kehidupan sehari-hari dapat menggunakan pengetahuan yang telah dimilikinya untuk menyelesaikan permasalahan tersebut. Tujuan dari penelitian ini yaitu menghasilkan produk hasil pengembangan soal tes untuk mengukur kemampuan pemecahan masalah siswa pada materi bentuk aljabar yang valid dan reliabel. Hasil tes yang telah dikembangkan diharapkan dapat digunakan guru untuk mengukur kemampuan pemecahan masalah siswa dalam pembelajaran matematika khususnya pada materi bentuk aljabar.

\section{METODE PENELITIAN}

Jenis penelitian ini adalah penelitian pengembangan dengan model $A D D I E$ singkatan dari Analysis, Design, Development, Implementation, and Evaluation (Rayanto, 2020). Beberapa kegiatan yang dilakukan pada setiap tahap model ADDIE meliputi: (1) Analysis, tujuan pada tahap ini ialah untuk menentukan dan menetapkan perlunya pengembangan produk dan kelayakan syarat-syarat produk. Kegiatan pada tahap ini antara lain: analisis kebutuhan, analisis kurikulum, dan analisis kompetensi dasar; (2) Design, tujuan pada tahap ini ialah untuk menyiapkan rancangan produk. Kegiatan pada tahap ini antara lain: pembuatan kisi-kisi dan mendesain template penyajian tes; (3) Development, tujuan pada tahap ini adalah untuk menghasilkan produk berupa tes untuk mengukur kemampuan pemecahan masalah pada materi bentuk aljabar yang telah direvisi

Alifmatika: Jurnal Pendidikan dan Pembelajaran Matematika, Desember 2021, Vol. 3, No. 2 


\section{Tita Elisya Wibowo \& Siti Faizah}

sesuai masukan para ahli. Kegiatan pada tahap ini antara lain: pembuatan soal tes berdasarkan kisi-kisi yang telah dibuat pada tahap design. Kemudian dilakukan validasi oleh ahli terhadap produk yang dikembangkan. Validasi dilakukan oleh 2 orang ahli sebagai validator yaitu 1 dosen pendidikan matematika dan 1 guru matematika. Kedua validator menilai produk dari aspek materi/isi, konstruk, dan bahasa (Yusrizal, 2016). Masukan dari validator digunakan sebagai acuan untuk merevisi produk yang dikembangkan; 4) Implementation, tujuan pada tahap ini ialah untuk memeroleh data berupa skor hasil pengerjaan siswa. Data diperoleh dengan mengujicobakan produk yang telah valid berdasarkan ahli kepada subjek uji coba; dan (5) Evaluation, tujuan pada tahap ini ialah untuk mengetahui validitas empiris dan reliabilitas dari produk yang dikembangkan. Tujuan tersebut dapat tercapai dengan cara menganalisis data uji validitas empiris dan reliabilitas yang diperoleh dari tahap implementation. Pada tahap ini juga dilakukan revisi terhadap produk. Revisi dilakukan berdasarkan evaluasi dari hasil pekerjaan siswa pada kegiatan uji coba. Setelah melalui kelima tahap tersebut, maka dihasilkan produk akhir. Pemilihan subjek uji coba dalam penelitian ini berdasarkan teknik simple random sampling yaitu pemilihan sampel secara acak yang didasarkan karena seluruh siswa kelas VII di MTs Salafiyah Syafi'iyah Seblak Jombang tahun ajaran 2020/2021 dianggap memiliki kemampuan yang seragam sehingga terpilih kelas VII C sebagai subjek uji coba. Teknik pengumpulan data dalam penelitian ini yaitu angket validasi dan tes. Sedangkan instrumen penelitian yang digunakan dalam pengumpulan data penelitian ini adalah lembar angket validasi dan lembar tes. Teknik analisis data meliputi analisis data validasi ahli, analisis data uji validitas empiris, dan analisis data uji reliabilitas. Adapun rumus yang digunakan untuk menganalisis data adalah sebagai berikut.

1. Analisis data validasi ahli

Data validasi ahli berupa penilaian yang diberikan oleh ahli untuk menilai kevalidan dari produk yang dikembangkan dari aspek materi/isi, kontruks, dan bahasa. Data hasil validasi ahli dianalisis secara manual menggunakan rumus: $V R=\frac{\sum_{i=1}^{n} \nabla_{I}}{n}$ dengan $V R=$ rata-rata validitas, $\bar{V}_{I}=$ rata-rata skor tiap validator, dan n=banyaknya validator (Riyani, Maizora, \& Hanifah, 2017). Kemudian, skor ratarata validator diinterpretasikan berdasarkan Tabel 1.

Tabel 1. Kriteria Validitas Ahli

\begin{tabular}{cc}
\hline Interval Skor & Kriteria \\
\hline $3 \leq V R<4$ & Sangat Valid \\
$2 \leq V R<3$ & Valid \\
$1 \leq V R<2$ & Kurang Valid \\
$0 \leq V R<1$ & Tidak Valid \\
\hline
\end{tabular}

Riyani et al., (2017) 
Produk yang dikembangkan dikatakan valid oleh ahli jika skor rata-rata validitas berada dalam interval $2 \leq V R<4$, maka produk layak untuk

diujicobakan. Namun jika skor rata-rata validitas berada dalam interval $0 \leq V R<2$, maka produk harus direvisi terlebih dahulu kemudian divalidasi oleh

ahli kembali sampai produk layak untuk diujicobakan.

2. Analisis data uji validitas empiris

Data uji validitas empiris diperoleh dari hasil uji coba tes yang berupa skor siswa. Data ini dianalisis menggunakan rumus korelasi product moment dengan berbantuan SPSS 16.0. Tujuan dari analisis ini adalah untuk memeriksa kualitas dari item soal pada tes yang dikembangkan. Menurut Arikunto (2013) item soal pada tes yang dikembangkan dikatakan valid jika $r_{\text {hitung }}>r_{\text {tabel }}$ dengan taraf

signifikan $5 \%$ begitu juga arti sebaliknya. Item tes yang dinyatakan tidak valid

harus direvisi lagi kemudian diujicobakan kembali sampai item soal valid.

3. Analisis data uji reliabilitas

Data uji reliabilitas diperoleh dari hasil uji coba tes yang berupa skor siswa. Namun data uji reliabilitas yang dianalisis hanya item soal yang telah dikatakan valid pada uji validitas empiris. Data ini dianalisis menggunakan rumus alpha chronbach dengan berbantuan SPSS 16.0. Kemudian, hasil analisis diinterpretasikan berdasarkan Tabel 2.

Tabel 2. Kriteria Reliabilitas

\begin{tabular}{cc}
\hline Interval nilai reliabilitas & Kriteria \\
\hline $0,00<r_{11} \leq 0,20$ & Sangat Rendah \\
$0,20<r_{11} \leq 0,40$ & Rendah \\
$0,40<r_{11} \leq 0,70$ & Sedang \\
$0,70<r_{11} \leq 0,90$ & Tinggi \\
$0,90<r_{11} \leq 1,00$ & Sangat Tinggi \\
\hline
\end{tabular}

Riyani et al. (2017)

Tes yang dikembangkan dikatakan reliabel apabila nilai reliabilitas berada dalam interval $0,40<r_{11} \leq 1,00$ (Arikunto, 2013).

\section{HASIL DAN PEMBAHASAN}

Pengembangan soal tes untuk mengukur kemampuan pemecahan masalah pada materi bentuk aljabar melalui beberapa tahapan sebagai berikut.

1. Analysis

Pada tahap ini dilakukan berbagai kegiatan analisis antara lain: analisis kebutuhan, analisis kurikulum, dan analisis kompetensi dasar. Berikut penjelasan dari masing-masing kegiatan yang diakukan.

Alifmatika: Jurnal Pendidikan dan Pembelajaran Matematika, Desember 2021, Vol. 3, No. 2 


\section{Tita Elisya Wibowo \& Siti Faizah}

a. Analisis kebutuhan

Kegiatan ini diawali dengan mengumpulkan berbagai teori dari ahli yang berhubungan dengan permasalahan dalam penelitian, kemudian dilanjutkan dengan mengkaji teori-teori tersebut untuk mendapatkan solusi yang tepat dari permasalahan atau untuk memenuhi kebutuhan. Teori-teori tersebut tentang kaidah penulisan tes uraian, syarat kelayakan tes uraian, dan indikator pemecahan masalah. Berdasarkan hasil kajian terhadap kaidah penulisan tes uraian diperoleh bahwa terdapat tiga aspek yang harus diperhatikan penyusun tes yaitu aspek materi/isi, aspek konstruk, dan aspek bahasa. Pada aspek materi penyusun tes harus memerhatikan bahwa tujuan tes sesuai dengan materi yang diajarkan oleh guru, pada aspek konstruk penyusun tes harus memerhatikan bahwa bentuk tes yang dibuat sesuai dengan tujuan dari tes, dan pada aspek bahasa penyusun tes harus memerhatikan bahasa yang digunakan dalam tes (Yusrizal, 2016). Selain itu, dalam menyusun tes untuk mengukur kemampuan pemecahan masalah item-item soal harus memenuhi indikator-indikator pemecahan masalah. Pada penelitian ini, indikator pemecahan masalah yang digunakan mengacu pada langkah-langkah pemecahan masalah matematika menurut Polya yang terdiri atas empat langkah yaitu memahami masalah, membuat rencana pemecahan masalah, melaksanakan rencana pemecahan masalah, dan memeriksa kembali hasil pemecahan masalah (Medyasari et al., 2020). Kemudian berdasarkan hasil kajian terhadap syarat kelayakan tes diperoleh bahwa sebuah tes dikatakan layak dan memiliki kualitas yang baik apabila memenuhi kriteria validitas dan reliabilitas (Arifin, 2009).

b. Analisis kurikulum

Kegiatan yang dilakukan ialah mengkaji kurikulum 2013 yang diterapkan di MTs Salafiyah Syafi'iyah Seblak Jombang. Pengkajian dilakukan untuk menetapkan kesesuaian kurikulum yang digunakan sekolah dengan tujuan pengembangan.

c. Analisis kompetensi dasar

Kegiatan yang dilakukan ialah menelaah kompetensi dasar pada materi bentuk aljabar. Berdasarkan hasil telaah tersebut dipilih kompetensi dasar sub bab operasi hitung aljabar yaitu menyelesaikan masalah yang berkaitan dengan operasi pada bentuk aljabar. Indikator item soal yang harus dicapai oleh siswa dikembangkan dengan memerhatikan kompetensi dasar dan indikator pemecahan masalah yang berlandaskan pada langkah-langkah pemecahan masalah Polya. Terdapat empat langkah pemecahan masalah Polya yaitu: 1) memahami permasalahan; 2) membuat rencana penyelesaian dari permasalahan yang ada; 3 ) melaksanakan rencana yang telah dibuat; dan 4) memeriksa kembali jawaban untuk melihat kesesuaian dari penyelesaian yang diberikan dengan permasalahan yang ada (Faizah, Nusantara, Sudirman, \& Rahardi, 2020). Berikut merupakan indikator pemecahan masalah Polya termodifikasi dapat dilihat di Tabel 3.

Alifmatika: Jurnal Pendidikan dan Pembelajaran Matematika, Desember 2021, Vol. 3, No. 2 
Tabel 3. Indikator Pemecahan Masalah Polya Termodifikasi

\begin{tabular}{cll}
\hline No. & $\begin{array}{c}\text { Langkah Pemecahan } \\
\text { Masalah Polya }\end{array}$ & \multicolumn{1}{c}{ Indikator Pemecahan Masalah } \\
\hline 1 & Memahami masalah & $\begin{array}{l}\text { Siswa menuliskan unsur-unsur yang diketahui } \\
\text { dan apa yang ditanya dari soal }\end{array}$ \\
2 & $\begin{array}{l}\text { Membuat rencana } \\
\text { pemecahan masalah } \\
\text { Siswa merencanakan strategi/rumus yang akan } \\
\text { digunakan untuk memecahkan masalah } \\
\text { pelaksanakan rencana } \\
\text { Memeriksa kembali }\end{array}$ & $\begin{array}{l}\text { Siswa menyelesaikan permasalahan pada soal } \\
\text { dengan strategi/rumus yang telah direncanakan } \\
\text { Siswa mengecek kembali hasil yang diperoleh } \\
\text { pada setiap langkah pemecahan masalah dan } \\
\text { membuat kesimpulan dari masalah yang telah } \\
\text { diselesaikan }\end{array}$ \\
& &
\end{tabular}

Medyasari et al. (2020)

2. Design

Pada tahap ini dilakukan berbagai perencanaan di antaranya:

a. Pembuatan kisi-kisi yang di dalamnya memuat nama sekolah, mata pelajaran, materi pokok, kelas/semester, tahun ajaran, bentuk soal, alokasi waktu, kompetensi inti, kompetensi dasar, indikator pemecahan masalah, indikator soal, level kognitif/dimensi kognitif, dan nomor soal.

b. Mendesain template penyajian soal. Pendesainan template dilakukan dengan tujuan agar item-item soal yang termuat dalam tes dapat disajikan dengan baik. Template didesain dengan memerhatikan format huruf, penyajian gambar pada soal, dan urutan letak bagian-bagian yang ada di dalam template. Bagian-bagian tersebut meliputi kop tes, tujuan tes, nama sekolah, mata pelajaran, materi pokok yang diteskan, kelas/semester, alokasi waktu pengerjaan tes, hari/tanggal pengerjaan tes, petunjuk pengerjaan tes, dan item-item soal.

3. Development

Pada tahap ini dilakukan berbagai kegiatan di antaranya:

a. Pembuatan tes, berdasarkan kisi-kisi yang telah dibuat di tahap design. Tes dibuat dengan tetap memerhatikan kaidah penulisan tes uraian dari aspek materi/isi, konstruk, dan bahasa serta indikator pemecahan masalah. Kemudian tes dirancang sesuai template yang telah dibuat di tahap design.

b. Tes yang telah dibuat kemudian divalidasi oleh ahli, validasi dilakukan oleh ahli sebagai validator yang terdiri 1 dosen pendidikan matematika Universitas Hasyim Asy'ari Tebuireng (validator 1) dan 1 guru matematika (validator 2) dengan memberikan lembar validasi sebagai acuan penilaian. Validasi ini ditinjau dari aspek materi/isi, konstruk, dan bahasa. Hal ini bertujuan memeroleh penilaian dan masukan dari validator sehingga tes yang dikembangkan benar-benar layak untuk diujicobakan. Hasil validasi tes oleh ahli sebagai validator dapat dilihat pada Tabel 4 . 
Tabel 4. Hasil Analisis Validasi Ahli

\begin{tabular}{|c|c|c|c|c|c|c|c|c|c|c|c|c|c|}
\hline \multirow{3}{*}{ Validator } & \multicolumn{12}{|c|}{ Aspek penilaian } & \multirow{3}{*}{$\begin{array}{l}\text { Rata-rata } \\
\text { skor tiap } \\
\text { validator }\end{array}$} \\
\hline & \multicolumn{4}{|c|}{ Materi/isi } & \multicolumn{4}{|c|}{ Konstruk } & \multicolumn{4}{|c|}{ Bahasa } & \\
\hline & 1 & 2 & 3 & 4 & 5 & 6 & 7 & 8 & 9 & 10 & 11 & 12 & \\
\hline 1 & 3 & 3 & 4 & 4 & 4 & 4 & 4 & 4 & 3 & 4 & 4 & 4 & 3,75 \\
\hline 2 & 4 & 4 & 4 & 4 & 3 & 4 & 4 & 4 & 3 & 3 & 4 & 4 & 3,75 \\
\hline \multicolumn{13}{|c|}{ Rata-rata skor validitas keseluruhan } & 3,75 \\
\hline \multicolumn{13}{|c|}{ Kriteria } & Sangat valid \\
\hline
\end{tabular}

Berdasarkan Tabel 4 diperoleh bahwa hasil validasi ahli terhadap tes yang dikembangkan menunjukkan rata-rata validitas 3,75 dan berada pada kriteria sangat valid sehingga tes ini dinilai layak untuk diujicobakan. Namun, terdapat komentar dan masukan ahli terhadap item-item soal dalam tes yang telah dikembangkan. Komentar dan masukan ahli dapat dilihat pada Tabel 5.

Tabel 5. Komentar dan Masukan Ahli

\begin{tabular}{cl}
\hline Ahli & \multicolumn{1}{c}{ Komentar dan Masukan } \\
\hline Validator 1 & $\begin{array}{l}\text { Perbaiki kalimat dalam soal supaya lebih jelas dan tidak } \\
\text { ambigu }\end{array}$ \\
Validator 2 & $\begin{array}{l}\text { Soal sudah baik, namun soal terlalu banyak menggunakan } \\
\text { materi bangun datar. Sebaiknya di nomor awal soal berupa } \\
\text { aljabar yang sederhana kemudian bertingkat kesulitannya. }\end{array}$ \\
\hline
\end{tabular}

Berdasarkan Tabel 5, kemudian dilakukan revisi terhadap item-item soal pada tes yang dikembangkan. Berikut salah satu hasil revisi item soal pada tes yang dikembangkan.

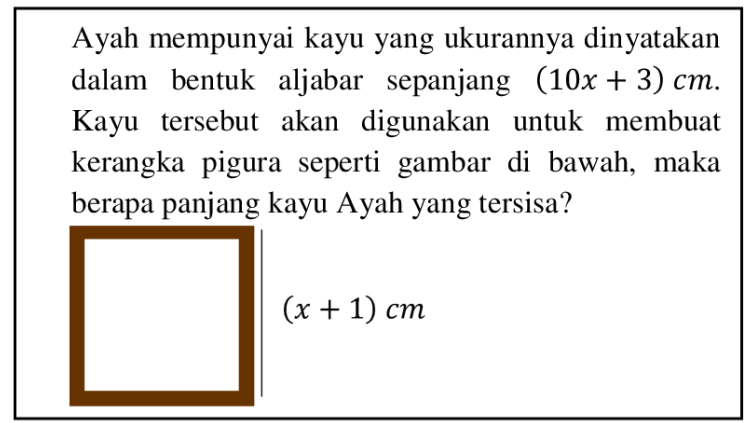

Sebelum Revisi
Ayah mempunyai sebuah kayu yang akan digunakan untuk membuat sebuah kerangka pigura seperti gambar di bawah. Jika panjang kayu dinyatakan dalam $(10 x+3) \mathrm{cm}$, maka berapa sisa panjang kayu Ayah?

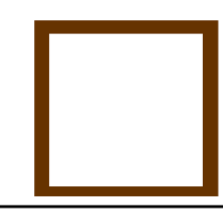

$(x+1) \mathrm{cm}$

Setelah Revisi

Gambar 1. Salah Satu Hasil Revisi pada Item Soal

\section{Implementation}

Pada tahap ini dilakukan uji coba tes hasil revisi dari tahap development kepada 17 siswa kelas VII C MTs Salafiyah Syafi'iyah Seblak Jombang. Uji coba dilakukan dengan tujuan untuk memeroleh data berupa skor hasil pengerjaan siswa untuk mengetahui validitas empiris dan reliabilitas dari tes yang

Alifmatika: Jurnal Pendidikan dan Pembelajaran Matematika, Desember 2021, Vol. 3, No. 2 
dikembangkan. Tes yang diujicobakan terdiri atas lima item soal dalam bentuk uraian dengan durasi waktu pengerjaan selama 60 menit.

\section{Evaluation}

Pada tahap ini dilakukan analisis pada data uji validitas empiris dan reliabilitas yang diperoleh dari tahap implementation. Analisis uji validitas empiris dilakukan untuk mengetahui kualitas tiap item soal yang terdapat pada tes yang dikembangkan. Analisis ini dilakukan menggunakan rumus korelasi product moment dengan berbantuan SPSS 16.0. Sebelum menganalisis uji validitas empiris terlebih dahulu mencari $r_{\text {tabel }}$. Dengan jumlah subjek uji coba sebanyak 17 siswa dengan taraf signifikan $5 \%$ maka diperoleh $r_{\text {tabel }}=0,482$. Hasil uji validitas item soal dapat dilihat pada Tabel 6.

Tabel 6. Hasil Uji Validitas Empiris Terhadap Item Soal

\begin{tabular}{ccc}
\hline Item soal & $r_{\text {hitung }}$ & Kriteria \\
\hline 1 & 0,930 & Valid \\
2 & 0,776 & Valid \\
3 & 0,720 & Valid \\
4 & 0,748 & Valid \\
5 & 0,237 & Tidak valid \\
\hline
\end{tabular}

Berdasarkan Tabel 6 diketahui bahwa dalam analisis uji validitas empiris terhadap lima item soal pada tes yang dikembangkan terdapat satu item soal yang tidak valid dan empat lainnya valid. Empat item soal yang dinyatakan valid adalah nomor $1,2,3$, dan 4 karena nilai $r_{\text {hitung }}>r_{\text {tabel }}$ yang artinya terdapat korelasi

atau hubungan antara skor pada item soal nomor 1, 2, 3, dan 4 dengan skor total. Sehubungan dengan Arikunto (2013) menjelaskan bahwa item soal pada tes yang dikembangkan dikatakan valid jika $r_{\text {hitung }}>r_{\text {tabel }}$ dengan taraf signifikan $5 \%$.

Berdasarkan ulasan yang telah dipaparkan, maka keempat item soal yang valid dapat digunakan mengukur kemampuan pemecahan masalah siswa. Sedangkan satu item soal yang tidak valid adalah nomor 5 karena nilai $r_{\text {hitung }}<r_{\text {tabel }}$ artinya

tidak ada korelasi atau hubungan antara item soal nomor 5 dengan skor total sehingga item ini tidak dapat digunakan untuk mengukur kemampuan siswa. Dari hasil pekerjaan siswa pada item soal nomor 5 menunjukkan bahwa kebanyakan siswa mengalami kebingungan dan kesulitan dalam menyelesaikan item soal nomor 5. Hal ini kemungkinan disebabkan oleh kalimat atau unsur-unsur lainnya yang terdapat pada item soal nomor 5 kurang jelas. Sehubungan dengan Yusrizal (2016) menjelaskan bahwa terdapat beberapa faktor internal dari soal yang menyebabkan sebuah soal tidak valid yaitu petunjuk pengerjaan soal yang disusun tidak jelas, kata-kata yang digunakan dalam soal kurang jelas, soal dikontruksi

Alifmatika: Jurnal Pendidikan dan Pembelajaran Matematika, Desember 2021, Vol. 3, No. 2 


\section{Tita Elisya Wibowo \& Siti Faizah}

dengan jelas, tingkat kesulitan soal tidak sesuai dengan materi yang diterima siswa, alokasi waktu tidak tepat, dan jumlah item terlalu sedikit sehingga tidak mewakili sampel. Oleh karena itu dilakukan revisi terhadap item soal nomor 5.

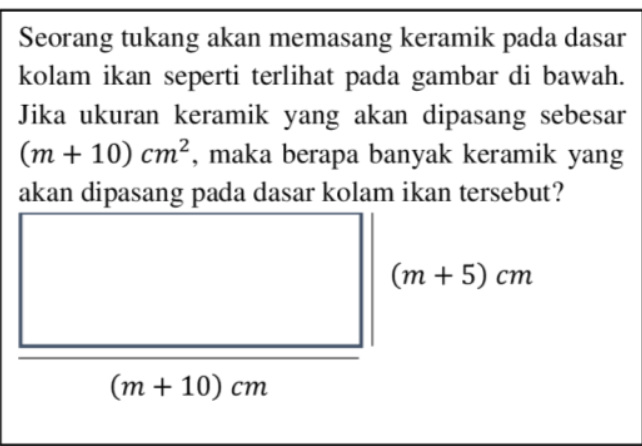

Sebelum Revisi

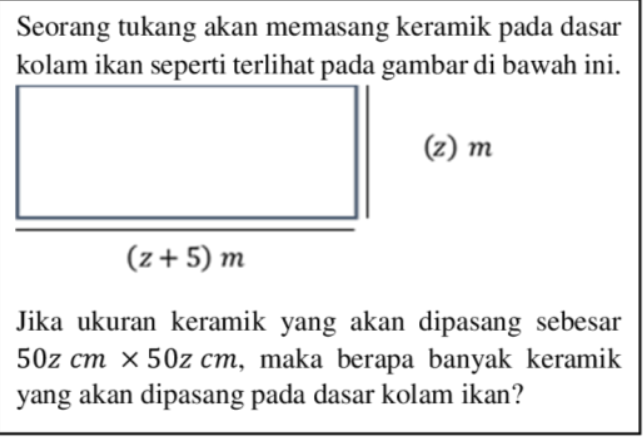

Setelah Revisi

Gambar 2. Hasil Revisi Item Soal Nomor 5

Setelah direvisi, item soal nomor 5 harus diujicobakan kembali. Namun mengingat waktu yang dimiliki terbatas, maka diambil keputusan bahwa item soal yang telah direvisi tersebut tidak diujicobakan kembali. Kemudian dilanjutkan dengan analisis uji reliabilitas. Analisis ini hanya dilakukan pada empat item soal yang dinyatakan valid pada uji validitas empiris. Analisis ini dilakukan dengan rumus alpha chronbach dengan berbantuan SPSS 16.0. Hasil uji reliabilitas item soal dapat dilihat pada Tabel 7.

Tabel 7. Hasil Uji Reliabilitas Item Soal

\begin{tabular}{cc}
\hline Nilai reliabilitas & Kriteria \\
\hline 0,786 & Tinggi \\
\hline
\end{tabular}

Berdasarkan Tabel 7 diketahui bahwa keempat item soal yang telah dinyatakan valid secara empirik dan diuji reliabilitasnya menunjukkan nilai reliabilitas sebesar 0,786 dan berada dalam kriteria tinggi sehingga tes yang dikembangkan dinyatakan reliabel. Sehubungan dengan Arikunto (2013) menjelaskan bahwa item soal pada tes yang dikembangkan dikatakan reliabel apabila nilai reliabilitas berada dalam interval $0,40<r_{11} \leq 1,00$. Berdasarkan

ulasan yang telah dipaparkan, maka dapat diartikan bahwa tes yang dikembangkan jika digunakan berulang untuk mengukur kemampuan subjek yang sama atau berbeda dan pada waktu yang sama atau berbeda maka hasil tes tetap atau konsisten.

Penelitian ini sejalan dengan penelitian yang telah dilakukan Angriani et al. (2018) dan Sinaga (2016) yaitu menghasilkan sebuah produk pengembangan tes yang digunakan untuk mengukur kemampuan pemecahan masalah siswa tingkat SMP/MTs. Berdasarkan hasil penelitian, maka dapat dibuktikan bahwa produk yang dikembangkan berupa tes yang terdiri atas lima item soal hanya empat item soal yang memenuhi kriteria validitas dan reliabilitas. Hal ini juga sehubungan 
dengan Arifin (2009) menjelaskan bahwa sebuah tes dikatakan layak dan berkualitas jika memenuhi dua kriteria yaitu validitas dan reliabilitas. Keempat item soal pada tes yang dikembangkan yang telah dinyatakan layak dan berkualitas baik dapat digunakan untuk mengukur kemampuan pemecahan masalah siswa pada materi bentuk aljabar. Selain untuk mengukur, tes yang dikembangkan juga dapat digunakan sebagai sarana untuk melatih kemampuan pemecahan masalah siswa karena soal-soal yang diberikan menantang pikiran dan tidak secara otomatis dapat diketahui penyelesaiannya. Menurut Lestari \& Yudhanegara (2015) setelah mengetahui sejauh mana kemampuan pemecahan masalah siswa pada materi bentuk aljabar melalui tes yang dikembangkan, guru dapat menyusun strategi pembelajaran yang tepat sehingga dapat meningkatkan kemampuan pemecahan masalah siswa dengan begitu dapat kualitas serta hasil belajar siswa juga meningkat. Sejalan dengan Sinaga (2016) menjelaskan bahwa kegiatan pengukuran kemampuan siswa dapat membantu guru dalam mengetahui pengetahuan dan keterampilan yang dikuasai oleh siswa serta dapat mengetahui penyebab ketidakberhasilan siswa dalam pembelajaran secara efektif sehingga mutu kegiatan belajar dan hasil belajar siswa dapat meningkat.

\section{KESIMPULAN DAN SARAN}

Berdasarkan hasil dan pembahasan mengenai pengembangan soal tes untuk mengukur kemampuan pemecahan masalah pada materi bentuk aljabar dapat ditarik kesimpulan bahwa produk yang dihasilkan berupa tes yang memuat lima item soal dimana empat item soal telah memenuhi kriteria validitas baik teoritis maupun empiris dan reliabilitas. Sedangkan satu item soal tidak memenuhi kriteria validitas empiris. Item soal yang tidak memenuhi kriteria validitas empiris kemudian direvisi berdasarkan penyebab ketidakvalidannya namun karena waktu terbatas item tersebut tidak diujicobakan kembali sehingga belum diketahui kevalidannya secara empiris. Jadi hanya empat item soal dalam tes yang dikembangkan yang dapat digunakan untuk mengukur kemampuan pemecahan masalah siswa pada materi bentuk aljabar. Berdasarkan kesimpulan tersebut, terdapat beberapa saran yang diusulkan yaitu: 1) disarankan kepada peneliti lain agar dapat mengujicobakan kembali soal tes yang telah dikembangkan ini agar dapat diketahui lebih lanjut tentang baik atau tidaknya soal tes kemampuan pemecahan masalah dengan syarat subjek uji coba adalah siswa sekolah menengah pertama sederajat kelas VII yang telah menerima materi bentuk aljabar; dan 2) disarankan kepada peneliti lain agar mengembangan soal tes kemampuan pemecahan masalah pada materi lain selain materi bentuk aljabar.

\section{UCAPAN TERIMA KASIH}

Kata terima kasih diucapkan kepada orang tua tercinta yang telah memberikan dukungan berupa moril maupun materil dan juga kepada Bapak/Ibu dosen pendidikan matematika Universitas Hasyim Asy'ari yang telah memberikan sumbangsinya baik langsung maupun tidak langsung.

Alifmatika: Jurnal Pendidikan dan Pembelajaran Matematika, Desember 2021, Vol. 3, No. 2 


\section{DAFTAR PUSTAKA}

Amam, A. (2017). Penilaian kemampuan pemecahan masalah matematis siswa SMP. Teorema: Teori Dan Riset Matematika, 2(1), 39-46. https://doi.org/10.25157/teorema.v2i1.765

Angriani, A. D., Nursalam, N., Fuadah, N., \& Baharuddin, B. (2018). Pengembangan Instrumen Tes untuk Mengukur Kemampuan Pemecahan Masalah Matematika Siswa. AULADUNA: Jurnal Pendidikan Dasar Islam, 5(2), 211-223. https://doi.org/10.24252/auladuna.v5i2a9.2018

Arifin, Z. (2009). Evaluasi pembelajaran. Bandung: PT Remaja Rosdakarya.

Arikunto, S. (2013). Dasar-Dasar Evaluasi Pendidikan Edisi Revisi. Jakarta: PT Bumi Aksara.

Arikunto, S. (2021). Dasar-Dasar Evaluasi Pendidikan Edisi 3. Jakarta: Bumi Aksara.

Faizah, S., Nusantara, T., Sudirman, S., \& Rahardi, R. (2020). Exploring students' thinking process in mathematical proof of abstract algebra based on Mason's framework. Journal for the Education of Gifted Young Scientists, 8(2), 871-884.

Hadi, S., \& Novaliyosi, N. (2019). TIMSS Indonesia (Trends in international mathematics and science study). Prosiding Seminar Nasional \& Call For Papers.

Hendriana, H., \& Sumarmo, U. (2014). Penilaian Pembelajaran Matematika Bandung. PT Refika Aditama Komunikasi Dan Representasi Matematis, Jurnal Pengajaran MIPA, 4(1), 6-9.

Hidayani, N. (2012). Bentuk Aljabar. PT Balai Pustaka (Persero).

Lestari, K. E., \& Yudhanegara, M. R. (2015). Penelitian pendidikan matematika. Bandung: PT Refika Aditama.

Medyasari, L. T., Zaenuri, Z., \& Dewi, N. R. (2020). Kemampuan pemecahan masalah matematis siswa SMA Negeri 5 Semarang. PRISMA, Prosiding Seminar Nasional Matematika, 3, 464-470.

Murni, A. (2014). Peningkatan kemampuan representasi matematis siswa SMP melalui pembelajaran metakognitif dan pembelajaran metakognitif berbasis soft skill. Jurnal Pendidikan, 4(2), 96-107. https://doi.org/10.31258/jp.4.2.96107

Permendikbud, P. (2016). Peraturan Menteri Pendidikan dan Kebudayaan Nomor 24 Tahun 2016 tentang Kompetensi Inti dan Kompetensi Dasar Pelajaran pada Kurikulum 2013 pada Pendidikan Dasar dan Menengah. Retrieved from https://bsnp-indonesia.org/2016/08/peraturan-menteri-pendidikan-dankebudayaan-nomor-24-tahun-2016/

Rambe, A. Y. F., \& Afri, L. D. (2020). Analisis Kemampuan Pemecahan Masalah Matematis Siswa dalam Menyelesaikan Soal Materi Barisan dan Deret. AXIOM: Jurnal Pendidikan Dan Matematika, 9(2), 175-187.

Rayanto, Y. H. (2020). Penelitian Pengembangan Model ADDIE dan R2D2: Teori dan Praktek. Pasuruan: Lembaga Academis \& Research Institute. 
Riyani, R., Maizora, S., \& Hanifah, H. (2017). Uji Validitas Pengembangan Tes Untuk Mengukur Kemampuan Pemahaman Relasional Pada Materi Persamaan Kuadrat Siswa Kelas Viii Smp. Jurnal Penelitian Pembelajaran Matematika Sekolah (JP2MS), 1(1), 60-65. https://doi.org/10.33369/jp2ms.1.1.60-65

Sanjaya, W. (2017). Perencanaan \& desain sistem pembelajaran. Jakarta: Kencana Prenadamedia Group.

Schleicher, A. (2019). PISA 2018: Insights and Interpretations. OECD Publishing.

Setiyawan, R. A., \& Wijayanti, P. S. (2020). Analisis Kualitas Instrumen Untuk Mengukur Kemampuan Pemecahan Masalah Siswa Selama Pembelajaran Daring Di Masa Pandemi. Jurnal Lebesgue: Jurnal Ilmiah Pendidikan Matematika, Matematika Dan Statistika, 1(2), 130-139. https://doi.org/10.46306/lb.v1i2.26

Sinaga, N. A. (2016). Pengembangan tes kemampuan pemecahan masalah dan penalaran matematika siswa SMP kelas VIII. Pythagoras: Jurnal Pendidikan Matematika, 11(2), 169-181. https://doi.org/10.21831/pg.v11i2.10642

Sumartini, T. S. (2016). Peningkatan kemampuan pemecahan masalah matematis siswa melalui pembelajaran berbasis masalah. Mosharafa: Jurnal Pendidikan Matematika, 5(2), 148-158. https://doi.org/10.31980/mosharafa.v5i2.270

Tarigan, D. E. (2012). Analisis kemampuan pemecahan masalah matematika berdasarkan langkah-langkah POLYA pada materi sistem persamaan linear dua variabel bagi siswa kelas VIII SMP negeri 9 Surakarta ditinjau dari kemampuan penalaran siswa. Surakarta: UNS (Sebelas Maret University).

Tohir, M. (2016). Hasil PISA Indonesia tahun 2015 mengalami peningkatan. Jurnal Researchgate.(1-2).

Tohir, M. (2019). Hasil PISA Indonesia tahun 2018 turun dibanding tahun 2015. Paper of Matematohir, 2(1), 1-2.

Wijayanti, D. (2021). Analisis soal pemecahan masalah pada buku sekolah elektronik pelajaran matematika SD/MI. Majalah Ilmiah Sultan Agung, 49(123), 27-39.

Yusrizal, Y. (2016). Tanya Jawab Seputar Pengukuran, Penilaian, dan Evaluasi Pendidikan. Banda Aceh: Syiah Kuala University Press. 